\title{
thebmj
}

Letters Public health advances

\section{Concerns about tobacco control}

BMJ 2010; 341 doi: http://dx.doi.org/10.1136/bmj.c7294 (Published 20 December 2010) Cite this as: BMJ 2010;341:c7294

Tom Yates, doctor1, Martin McKee, professor of European public health2, Kate E Pickett, professor of epidemiology3, Martin Dockrell, director, policy and research4, Anna Gilmore, professor of public health, Health Foundation clinician scientist, and honorary consultant in public health medicine 51 , Gerard Hastings, professor of social marketing, and director6, Alan Maryon-Davis, honorary professor of public health7, Alexander Macara, former chairman of council8

${ }^{1}$ Medact, London N1 6HT, UK

${ }^{2}$ European Centre on Health of Societies in Transition, London School of Hygiene and Tropical Medicine, London WC1H $9 S H, U K$

${ }^{3}$ Department of Health Sciences, University of York, York YO10 5DD, UK

${ }^{4}$ ASH Action on Smoking and Health, London E1 6JE

${ }^{5}$ Department for Health, University of Bath, Bath BA2 7AY, UK

${ }^{6}$ Institute for Social Marketing and the Centre for Tobacco Control Research, University of Stirling and the Open University, Stirling FK9 4LA, UK

${ }^{7}$ Department of Primary Care and Public Health Sciences, King's College London School of Medicine, London SE1 3QD, UK

${ }^{8}$ BMA, London WC1H 9JP, UK

thomas.yates@medsci.ox.ac.uk

In discussing whether the UK is turning the clock back on public health advances, 1 the fact that the coalition government is considering mandatory plain brown packets for cigarettes is encouraging. 2 However, this move, which may get held up in the courts, must not delay implementing the proposals to ban tobacco vending machines and point of sale displays that accompanied the 2009 Health Act.

One in two smokers dies from their habit, and $59 \%$ of the difference in premature male mortality between rich and poor people in England and Wales can be explained by differential rates of smoking. 3 Bans on tobacco advertising reduce cigarette consumption, with the caveat that bans need to be comprehensive to be effective. 4

Ever larger back lit point of sale displays have been used by the tobacco industry in recent years to circumvent the advertising ban.5 Poorly supervised vending machines, while comprising a tiny proportion of total cigarette sales, are the means by which one in eight child smokers accesses their cigarettes. 6

Whereas the coalition government has confirmed that the ban on tobacco vending machines will go ahead, we remain concerned that it has failed to reassure parliament that it will implement the ban on point of sale displays in full. 


\section{Notes}

Cite this as: $B M J$ 2010;341:c7294

\section{Footnotes}

- Competing interests: Tobacco and tobacco control policies have an impact on all of the authors in both their professional and personal lives.

\section{References}

1. Wise J. Is the UK turning the clock back on public health advances? BMJ2010;341:c6691. 23 November.

2. Campbell D. Cigarettes "to be sold in plain brown packs." Guardian2010 Nov 20 www.guardian.co.uk/society/2010/nov/20/cigarettes-plain-brown-packs.

3. Jha P, Peto R, Zatonski W, Boreham J, Jarvis MJ, Lopez AD. Social inequalities in male mortality, and in male mortality from smoking: indirect estimation from national death rates in England and Wales, Poland, and North America. Lancet 2006;368:367-70.

4. World Bank. Curbing the epidemic: governments and the economics of tobacco control. 1999. Available from http://www1.worldbank.org/tobacco/cover2a.asp.

5. Action on Smoking and Health. Tobacco displays at the point of sale. 2010. www.ash.org.uk/files/documents/ASH 701.pdf.

6. NHS Information Centre for Health and Social Care. Smoking, drinking and drug use among young people in England in 2008. 2009. www.ic.nhs.uk/statistics-and-data-collections/health-and-lifestyles-relatedsurveys/smoking-drinking-and-drug-use-among-young-people-in-england/smoking-drinking-and-drug-use-amongyoung-people-in-england-in-2008-full-report. 